\title{
A new species of Saetherocryptus Andersen et Mendes, 2007 from Brazil (Diptera: Chironomidae, Orthocladiinae)
}

\author{
Trond Andersen ${ }^{1}$, Humberto Fonseca Mendes ${ }^{1,3}$ \& Luiz, Carlos Pinho ${ }^{2}$ \\ ${ }^{1}$ Department of Natural History, University Museum of Bergen, University of Bergen, \\ P.O. Box 7800, N-5020, Bergen, Norway, e-mail: trond.andersen@zmb.uib.no \\ ${ }^{2}$ Departamento de Ecologia e Zoologia - ECZ, Centro de Ciências Biológicas - CCB, \\ Universidade Federal de Santa Catarina - UFSC, Campus Trindade, \\ CEP 88040-900, Florianópolis, SC, Brazil, e-mail: lcpinho@ccb.ufsc.br \\ ${ }^{3}$ Corresponding author: Humberto Fonseca Mendes, e-mail: humberto.mendes@bm.uib.no
}

ANDERSEN, T., MENDES, H.F. \& PINHO, L.C. A new species of Saetherocryptus Andersen et Mendes, 2007 from Brazil (Diptera: Chironomidae, Orthocladiinae). Biota Neotrop. 11(4): http://www.biotaneotropica.org. br/v11n4/en/abstract?article+bn01411042011

Abstract: Saetherocryptus Andersen et Mendes, 2007 was described as monotypic, based on S. clavatus Andersen et Mendes, 2007 from Mata Atlântica in south and southeast Brazil. A second species, S. temimino sp. n., is described and figured below based on an adult male from São Paulo State.

Keywords: Saetherocryptus temimino, Orthocladiinae, Mata Atlântica, new species.

ANDERSEN, T., MENDES, H.F. \& PINHO, L.C. Uma nova espécie de Saetherocryptus Andersen et Mendes, 2007 para o Brasil (Diptera: Chironomidae, Orthocladiinae). Biota Neotrop. 11(4): http://www.biotaneotropica. org.br/v11n4/pt/abstract?article+bn01411042011

Resumo: Saetherocryptus Andersen et Mendes, 2007, até então monotípico, foi descrito com base em S. clavatus Andersen et Mendes, 2007 da Mata Atlântica do sul e sudeste do Brasil. Uma segunda espécie, S. temimino sp. n., é descrita e ilustrada abaixo com base em um macho adulto do Estado de São Paulo.

Palavras-chave: Saetherocryptus temimino, Orthocladiinae, Mata Atlântica, espécie nova. 


\section{Introduction}

Andersen \& Mendes (2007) described five new genera of Orthocladiinae from Brazil. The genus Oleia Andersen et Mendes, 2007 was based on seven species both from MataAtlântica and from Amazonas. The remaining four genera, Saetherocryptus Andersen et Mendes, 2007, Saetherocladius Andersen et Mendes, 2007, Saetherops Andersen et Mendes, 2007 and Saetherolabis Andersen et Mendes, 2007 were all monotypic. Andersen et al. (2010) added four new species of Saetheocladius from Mata Atlântica. Below we describe and figure a second species of Saetherocryptus, S. temimino sp. n., based on an adult male from São Paulo State. However, the genera Saetherops and Saetherolabis still remain monotypic.

\section{Material and Methods}

The specimen was mounted in Euparal following the procedures outlined by Sæther (1969). The general morphology follows Sæther (1980).

The holotype will be deposited in Museu de Zoologia da Universidade de São Paulo (MZUSP).

\section{SAETHEROCRYPTUS ANDERSEN ET MENDES}

Saetherocryptus Andersen et Mendes, 2007: 33.

Type-species: Saetherocryptus clavatus Andersen et Mendes, 2007: 35 , by original designation.

Other included species: Saetherocryptus temimino sp. n.

Saetherocryptus temimino shares with S. clavatus all the diagnostic characters proposed in the original description of the genus (see Andersen \& Mendes 2007), placing it well within Saetherocryptus.

Description as in Andersen \& Mendes (2007), with the following emendations: megaseta large, club-shaped to strongly curved; posterior margin of tergite IX subrectangular to rounded.

\section{SAETHEROCRYPTUS TEMIMINO SP. N. (FIGURES 1-8)}

Type Material: Holotype male: Brazil, São Paulo State, Salesópolis, Estação Biológica Boracéia, córrego Coruja, 18.ix.2007, light trap, C.G. Froehlich et al. (MZUSP).

Etymology: The name temimino is the name of an indigenous tribe that used to live in the area where the species was collected. The name is to be treated as a noun in apposition.

Diagnostic characters: The species can easily be separated from S. clavatus Andersen et Mendes based on the subtriangular shape of the gonostylus; the curved, pointed megaseta; the length of the costal extension ( $82 \mu \mathrm{m}$ against $104-166 \mu \mathrm{m}$ in $S$. clavatus); the more triangular dorsomedian projection of the gonocoxite that overreaches the base of the gonostylus; and the rounded posterior margin of tergite IX.

\section{Description}

Male $(\mathrm{n}=1)$ Total length $1.52 \mathrm{~mm}$. Wing length $1.01 \mathrm{~mm}$. Total length/wing length 1.50 . Wing length/length of profemur 2.82 .

Coloration. Light brown, without darker markings; legs and antennae slightly lighter than body; wing translucent.

Head. AR 0.48. Ultimate flagellomere $175 \mu \mathrm{m}$ long. Temporal setae 7, including 3 inner verticals, 3 outer verticals, and 1 postorbital. Clypeus with 6 setae, labrum with 16 setae. Tentorium and stipes as in Figure 1. Tentorium $75 \mu \mathrm{m}$ long, $14 \mu \mathrm{m}$ wide; stipes $61 \mu \mathrm{m}$ long, width not measurable. Palp as in Figure 2. Palp segment lengths/ widths (in $\mu \mathrm{m}$ ): 11/11, 16/14, 32/14, 34/ 10, 45/9. Third palpomere with 2 sensilla clavata subapically, $9 \mu \mathrm{m}$ long.

Thorax (Figure 3). Antepronotum bare. Dorsocentrals 7; acrostichals 8, weak, decumbent, biserial, in midscutum; prealars 3. Scutellum with 6 setae.
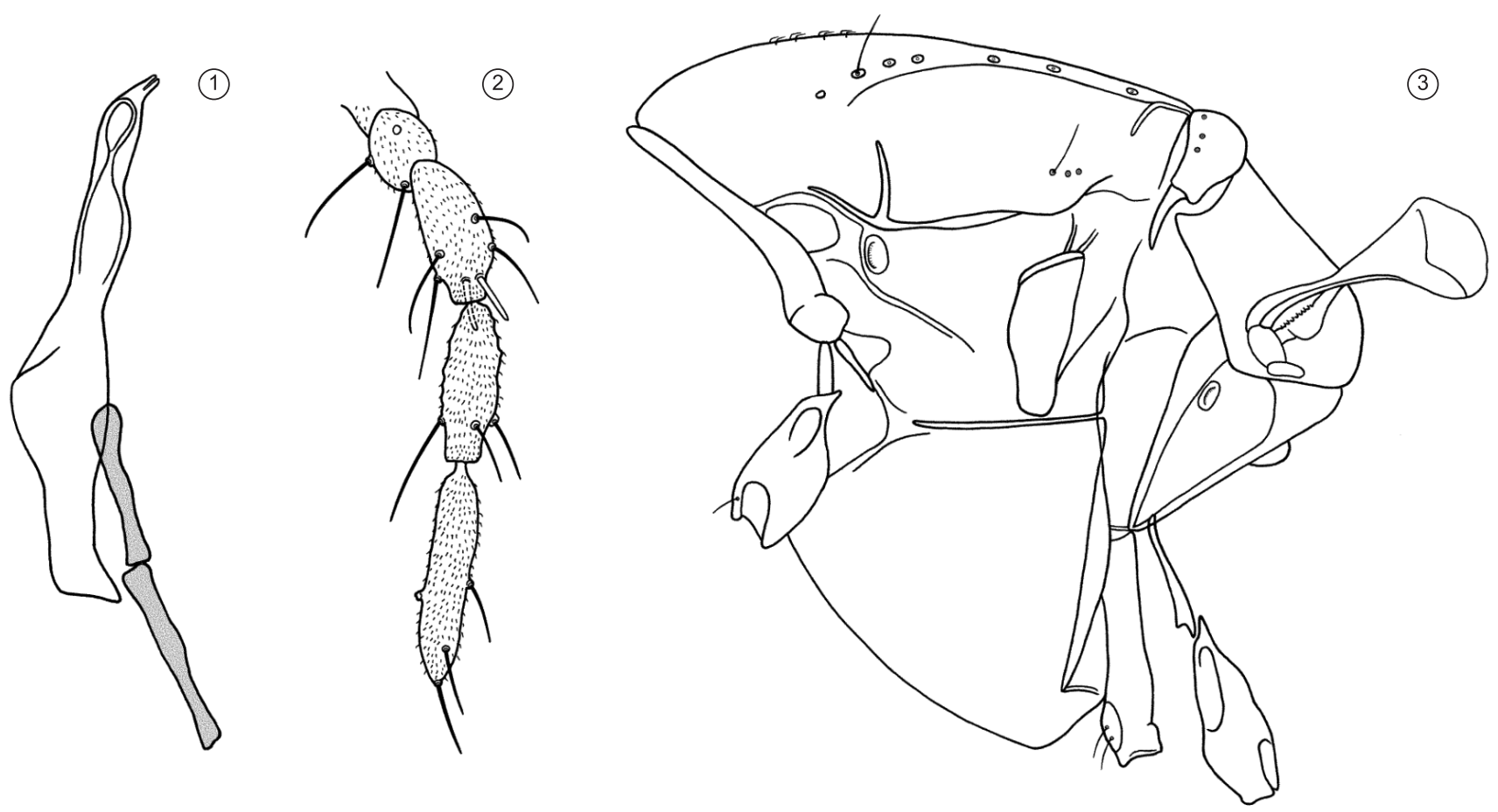

Figures 1-3. Saetherocryptus temimino sp. n., male. 1) Tentorium and stipes; 2) Palp; 3) Thorax. 

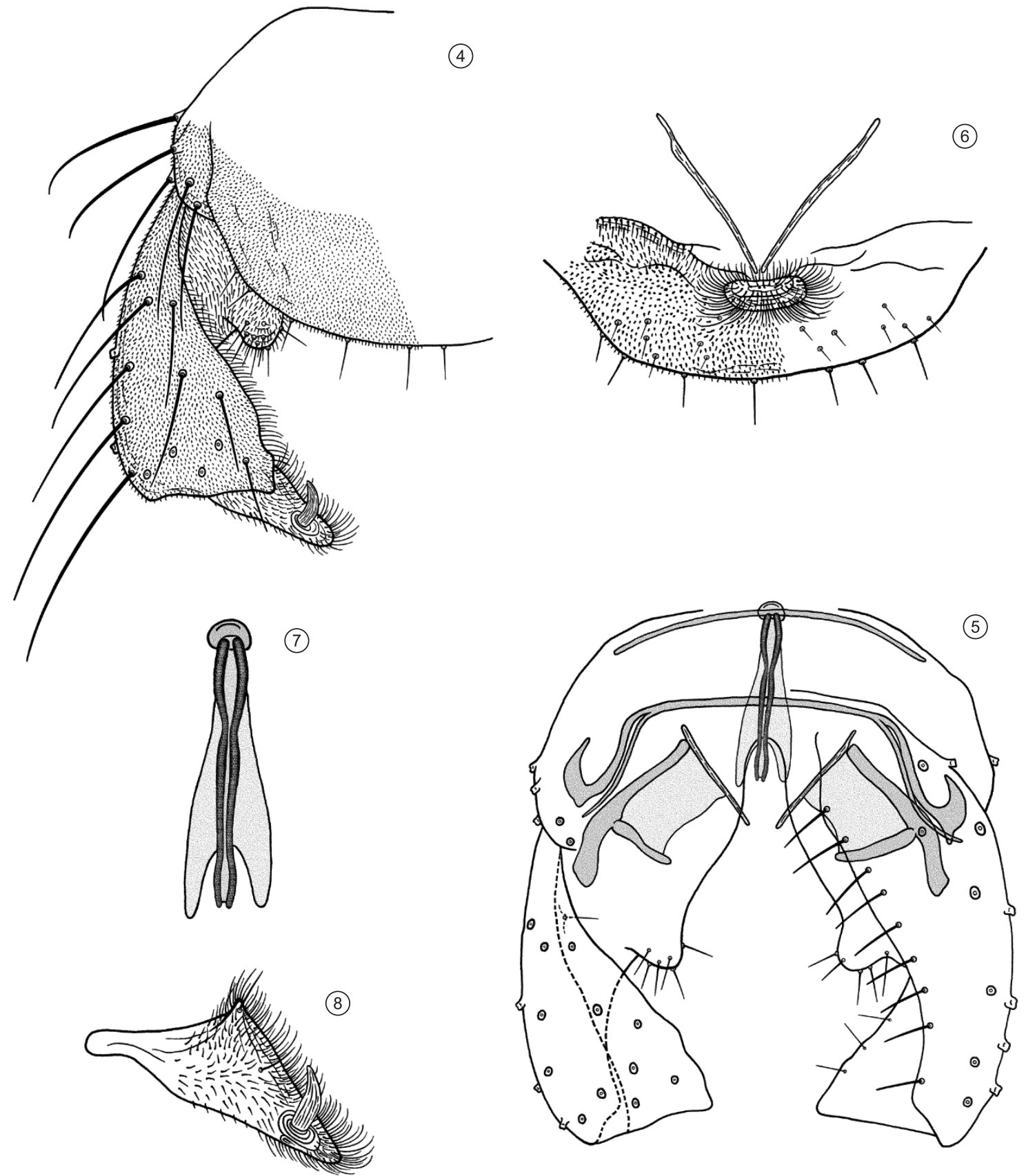

Figures 4-8. Saetherocryptus temimino sp. n., male. 4) Hypopygium, dorsal aspect; 5) Hypopygium with anal point and tergite IX removed, dorsal aspect to the left and ventral aspect to the right; 6) Anal point and ventral view of posterior margin of tergite IX; 7) Virga; 8) Gonostylus, dorsal view.

Wing. Folded during slide preparation; some measurements like VR or Sc could not be taken. Costal extension $82 \mu \mathrm{m}$ long. Brachiolum with 1 seta.

Legs. Spur of fore tibia $23 \mu \mathrm{m}$ long, spurs of mid tibia $15 \mu \mathrm{m}$ and $9 \mu \mathrm{m}$ long, spurs of hind tibia $25 \mu \mathrm{m}$ and $11 \mu \mathrm{m}$ long. Width at apex of fore- and mid tibia not measurable, of hind tibia $27 \mu \mathrm{m}$. Comb with 9 setae, longest $25 \mu \mathrm{m}$ long, shortest $16 \mu \mathrm{m}$ long. Lengths and proportions of legs as in Table 1 .

Hypopygium (Figures 4-8). Tergite IX $111 \mu \mathrm{m}$ wide; with broadly rounded posterior margin, dorsal surface with microtrichia but no setae except along margin, with coarse microtrichia on ventral surface. Anal point on ventral side, $8 \mu \mathrm{m}$ long, $18 \mu \mathrm{m}$ wide, with long, curved microtrichia. Laterosternite IX with 5 setae. Phallapodeme $59 \mu \mathrm{m}$ long; transverse sternapodeme nearly straight, $73 \mu \mathrm{m}$ long. Virga with 2 median spines, $54 \mu \mathrm{m}$ long, and lateral lamellae. Gonocoxite $137 \mu \mathrm{m}$ long; with triangular dorsomedian projection overreaching the base of the gonostylus, $54 \mu \mathrm{m}$ long, $27 \mu \mathrm{m}$ wide, with long microtrichia along inner margin. Inferior volsella rounded, $11 \mu \mathrm{m}$ long, $11 \mu \mathrm{m}$ wide, with 9 setae, apparently without sensilla trichoidea; ending $75 \mu \mathrm{m}$ from apex of gonocoxite. Gonostylus wedge shaped, $58 \mu \mathrm{m}$ long, covered with long microtrichia; megaseta situated subapically, widest at base and strongly curved, $14 \mu \mathrm{m}$ long, $4 \mu \mathrm{m}$ wide at base. HR 2.37, HV 2.62.

\section{Distribution and ecology}

This species is known only from the type locality in Estação Biológica Boracéia, São Paulo State, where it is sympatric with 
Andersen, T. et al.

Table 1. Lengths (in $\mu \mathrm{m}$ ) and proportions of legs of Saetherocryptus temimino sp. n., male $(\mathrm{n}=1)$.

\begin{tabular}{rcccrrrrrrrr}
\hline & $\mathbf{f e}$ & $\mathbf{t i}$ & $\mathbf{t a}_{\mathbf{1}}$ & $\mathbf{t a}_{\mathbf{2}}$ & $\mathbf{t a}_{\mathbf{3}}$ & $\mathbf{t a}_{\mathbf{4}}$ & $\mathbf{t a}_{\mathbf{5}}$ & $\mathbf{L R}$ & $\mathbf{B V}$ & $\mathbf{S V}$ & $\mathbf{B R}$ \\
\hline $\mathrm{p}_{1}$ & 371 & 443 & 212 & 151 & 88 & 47 & 32 & 0.48 & 3.22 & 3.83 & - \\
$\mathrm{p}_{2}$ & 403 & 436 & 164 & 86 & 68 & 30 & 25 & 0.38 & 4.76 & 5.12 & - \\
$\mathrm{p}_{3}$ & 443 & 482 & 256 & 130 & 104 & 43 & 31 & 0.53 & 3.81 & 3.62 & 3.3 \\
\hline
\end{tabular}

S. clavatus Andersen et Mendes. Saetherocryptus clavatus however is also recorded from several other localities in São Paulo and Santa Catarina States.

\section{Discussion}

During the last decade the number of Chironomidae species and genera described or recorded from Brazil has increased strongly. Today more than 380 species in 73 genera are known to occur in Brazil (Mendes \& Pinho 2011). Between 1999 and 2010 the number of species recorded from São Paulo State increased by nearly $500 \%$, from 31 species in 1999 to 149 species in 2010; the number of known Orthocladiinae species increased from 1 species in 1999 to 44 species in 2010 (Trivinho-Strixino 2011). This increase is partially due to the BIOTA project financed by the agency FAPESP that aimed to increase the knowledge and state of the art of the biodiversity of São Paulo State. However, as pointed out by Trivinho-Strixino (2011) at present the immature stages are known for only $24 \%$ of the Orthocladiinae species, while the corresponding figures are 70 and $77 \%$ for the subfamilies Chironominae and Tanypodinae, respectively. Although the larvae of many Orthocladiinae species might be terrestrial or semiterrestrial and difficult to locate, more effort should thus be placed on rearing and describing Orthocladiinae larvae and pupae during the coming decade.

\section{Acknowledgements}

Thanks are due to Dr. Claudio G. Froehlich for making the material of this new species available to us. L.C. Pinho also acknowledges FAPESP for the scholarship granted during completion of this paper (05/53026-0; 07/55833-6).

\section{References}

ANDERSEN, T. \& MENDES, H.F. 2007. Five enigmatic new orthoclad genera from Brazil (Diptera: Chironomidae: Orthocladiinae). In Contributions to the Systematics and Ecology of Aquatic Diptera. A Tribute to Ole A. Sæther (T. Andersen, ed.). The Caddis Press, Columbus, p.17-52.

ANDERSEN, T., MENDES, H.F. \& PINHO, L.C. 2010. Four new species of Saetherocladius Andersen et Mendes from Mata Atlântica, Brazil (Diptera: Chironomidae: Orthocladiinae). Zootaxa. 2608:45-56.

MENDES, H.F. \& PINHO, L.C. 2011. Brazilian chironomid home page. http:// sites.google.com/site/brazilianchironomids/(último acesso em 20/05/2011).

SÆTHER, O.A. 1969. Some Nearctic Podonominae, Diamesinae and Orthocladiinae (Diptera: Chironomidae). Bull. Fish. Res. Board Canada 107:1-154.

SÆTHER, O.A. 1980. Glossary of Chironomid morphology terminology (Diptera: Chironomidae). Ent. scand. Suppl. 14:1-51.

TRIVINHO-STRIXINO, S. 2011. Chironomidae (Insecta, Diptera, Nematocera) do Estado de São Paulo, Sudeste do Brasil. Biota Neotrop. 11:1-10. 